\title{
Crisis? What crisis? Some research-based reflections on police-press relations
}

The media are an influential contributor to promoting favourable images of policing, yet tension is endemic to the police-media relationship (Chibnall, 1977; Leishman and Mason, 2003; Reiner, 2007). Of late, the police-press relationship and police force processes for conducting media relations have been the focus of much scrutiny. In July 2011 the House of Commons Home Affairs Committee recorded concerns over senior officers of the Metropolitan Police Service accepting hospitality from senior members of News International. This was followed by Operations Elvedon and Weeting and reviews by HMIC (2011) and Elizabeth Filkin (2011). Subsequently module two, part one, of the Leveson Inquiry examined 'contacts and the relationship between the Press and the Police and the conduct of each' (http://www.levesoninquiry.org.uk/about/). Evidence was heard during March and April 2012 and was provided by current and former police leaders, senior investigating officers (SIOs), heads of corporate communications, representatives of staff associations, other policing stakeholders and a criminologist. The resulting headlines gave the impression that the police service's relationship with the media is in disarray, that senior police officers have become too close to senior media personnel, that hospitality is out of control and that internal markets exist for providing 'jobs for the boys' and work placements for sons and daughters.

However, amid the sensational headlines dominating the media coverage of the Leveson Inquiry, some significant points were raised concerning the principles and practice of police-media relations. These concern quite radical questions such as whether press offices are necessary and fit for purpose, mixed with more technical discussion of how press offices are resourced and whether greater regulation of police-press contacts would provide a solution to the perceived issues. Overlaying these debates, but not always well-defined have been the issue of differences between the Metropolitan Police service (the Met hereafter) and other forces in England and Wales and also the differences between police relations 
with the local and national media. This article reflects on these questions, considering what can be learned from existing research on the police-media relationship. The discussion that follows is largely based on three national surveys of police press offices (1996-7, 2000-1 and 2006-7) and ESRC funded research that included interviews with police communications managers and crime reporters ${ }^{1}$. The intention of the article, therefore, is to provide a research-informed contribution to the ongoing work towards consistent and transparent police-media relations. It concludes by proposing an outline framework for building-in communications to police work as an essential component of legitimate policing.

\section{Is it necessary for police forces to have press offices?}

In considering whether police force press offices are necessary, it should be noted that the first attempt to formalise police-media relations was Commissioner Sir Nevil Macready's decision to establish a 'press room' at Scotland Yard in October 1919. The catalyst for the room's establishment was a number of police scandals arising from leaked information. The leakage arose from the informal practice of detectives selling information to press reporters. Macready (1924: 417) recorded in his memoirs that he was concerned both with the inaccuracy of the reporting and also the principle that officers took money for information. But he wrote also that he wanted to 'dissipate the cloud of mystery in which Scotland Yard was supposed to be enveloped'. The limited functions of the new press room were insufficient to service the needs of the press and the informal practices continued.

It was not until the late 1960s that other forces followed the Met's example and established press offices. In the intervening period these departments have developed to the extent that 'press office' is now a misnomer. What used to be headquarters-based press offices typically managed and partly staffed by police officers with a responsibility for reactive media liaison have developed into departments responsible for internal communications, operational support, media liaison and public 
relations. They are most often called 'Corporate Communications' departments, employ professional communications staff, and have wide-ranging responsibilities with strategic and operational, internal and external dimensions (Mawby, 2007a). These include:

- News management: dealing with media enquiries, reactive and proactive media liaison; informing the public; managing media interest in incidents; promoting public reassurance messages; partnership communications.

- Operational support: responsibility for corporate communications strategies and media policies; major incident and crisis communications; facilitating interviews; developing internal communications; intra and internet development and management and e-communications; delivering media training.

- PR and marketing communications: protecting and promoting the force's reputation; proactive marketing of campaigns; maintaining and managing public relations; promoting public reassurance messages; corporate identity; merchandising; graphic design; audio-visual services; exhibitions and shows and events management.

Therefore, press offices have moved far beyond Macready's vision of providing an official and consistent conduit for the release of information to the public through the press; they now fulfil corporate communications functions that run through the police organisation. To support this, the model of a headquarters-focussed media function has been augmented by a trend towards communications 'permeating' the police organisation (Mawby, 2002). This comprises forces placing communications staff outside of headquarters departments in their territorial areas. $62 \%$ of forces did this in $2006-7$ 
compared with $29 \%$ in $2000-1$ and there were 146 communications staff deployed across Basic Command Units compared with 69 in 2000-1 (Mawby, 2007a).

Therefore the modern police 'press office' has wide-ranging functions that support the organisation as a whole. At its best, this represents an attempt to build-in rather than bolt-on non-operational communications as an integrated part of policing. This comes to the fore most publicly during serious crime investigations which attract intense media interest. In such cases, the police investigation comes under concentrated scrutiny which creates operational problems (Mawby, 2007b; Wilson et al., 2011). A number of cases have generated criticism that the existing police communications approach has failed to satisfy the media and control the flow of information (the Joanna Yeates murder investigation is a prime example, but the Fred and Rose West case in 1994 suffered from similar media intrusion issues, e.g., parallel enquiries conducted by the media, media questioning of police lines of enquiry, and the media paying witnesses for their stories). Such cases have led to questioning of the effectiveness of press offices, but this is also an area in which corporate communications have become part of operational policing and the media can be employed as an 'investigative resource' (Feist, 1999; Innes, 1999). Police communications personnel can support and advise the investigation team. As media professionals they can provide guidance on the level and types of media interest that the investigation will generate. They can work backstage assisting the SIO and their team with advice on information disclosure and on managing the consequences of media involvement. They can also work frontstage liaising direct with media representatives, thereby acting as a buffer between detectives and the media, allowing the investigation team to concentrate on substantive matters. Where the media demand to speak to the SIO, the press officer can broker and manage these appearances and can prepare the SIO for the questioning. Press officers can also act as a buffer between the media and members of the victim's family. Employing such measures allows the SIO to concentrate on the investigation and makes 
the maximum use of the skills of the police-employed media professionals, which in turn will help to meet the requirements of the media.

\section{Are press offices fit for purpose?}

As the functions of press offices have expanded, there has been a steady growth in the practice of police

forces appointing professional communicators. The numbers of these professionals have increased significantly. In 2006-7 there were at least 408 communications professionals employed across 42 responding forces compared with 215 in 2000-1 across all 51 forces in England, Wales and Scotland (Mawby, 2007a). These included trained journalists, public relations officers and marketers, but also audio-visual and graphic design technicians. This rise in police corporate communications has been documented elsewhere (Mawby, 2010b), but it is important not to overstate the case as the growth is inconsistent across forces. There are some stark contrasts in the resourcing of corporate communications which has implications for the consistency of communication nationally. This can be due to several factors. The size and profile of some forces and their geographical areas and the presence of media organisations will have an influence, as will the priorities and attitudes of the local ACPO team. If the chief officer is a communications advocate, their influence will set the force's communications style. A force's communications approach can change dramatically with a change of ACPO personnel (Mawby, 2002).

From a 'customer service' perspective, the growth in corporate communications is also balanced by the increase in demand across a range of responsibilities. Forces tend to experience annual increases in the number of daily contacts with media organisations (Mawby, 2007a). In addition, departments have experienced increases in demand relating to new media, to internal communications and to providing internal marketing consultancy. These demands have increased at a time when staff numbers have been under scrutiny due to forces striving to make efficiency savings. Recent research (Cartmell and Green, 
2011) suggests that a minority of departments (12 of 38 responding forces) maintained or increased their budgets during the financial year 2011-12, but the majority (26 of the 38 responding forces) faced reductions, with some departments experiencing cuts of up to $38 \%$. Consequently, the demands of the operating context ensure that corporate communications departments are 'running to stand still' (Mawby, 2007a).

With regard to the experiences of one group of external customers, namely crime reporters, they recognise the increasing professionalisation of police communications and identify mixed benefits. They appreciate the benefits of regular contacts with press officers, particularly former journalists, as 'they know the rules and talk on and off record, they'll tell you why they can't tell you things. You can have an honest conversation' (Mawby, 2010b). On the other hand crime reporters found that professionalisation did not necessarily mean a better service. They felt that the police lack understanding of the needs of the different media and, at times, engage in the strategic withholding and releasing of information. Consequently, despite the professionalisation trend, crime reporters use press offices as one but not their only source of information; they are a necessary but not sufficient element of the news production process. Other sources include members of the public and disgruntled police employees. However, the most important source remains regular police contacts, with whom crime reporters build and maintain relationships (Mawby 2010a).

\section{Is greater regulation of police-press contacts required?}

One facet of the police-media relationship that has been commented on in recent reports (Filkin, 2011; HMIC, 2011) and during the proceedings of the Leveson Inquiry, has been a debate concerning whether all police-press contacts should be recorded in order to regulate a transparent and auditable relationship between all police staff and press representatives. It is argued that this formalisation of police-media contacts would discourage the leaking of information and provide an audit trail. At the 
Leveson Inquiry, some chief constables supported a formal system (e.g., Jon Stoddard from Durham) whereas others (e.g., Mike Cunningham from Staffordshire) preferred the less formal method of officers recording contacts in their pocket books. Members of the press have lobbied against a formal system of recording all contacts. At a time when crime reporters believe that it is increasingly difficult to gain the confidence and cooperation of rank-and-file officers, they fear that the formal requirement will set up an obstacle to communication, resulting in the breakdown of their networks of informal sources that provide background information and ongoing policing and crime information. In short, greater regulation will threaten the routine processes of news gathering and crime reporting.

This situation crystallises a recurring tension of police-media relations. Examination of the history of police-media relations shows that police forces over time have had consistent objectives in establishing and maintaining their media relations. These are: (1) to control the flow and content of information between the force and the media; (2) to promote favourable images of policing; (3) to inform the public about policing matters; (4) to request information to assist with the prevention and detection of crime; and (5) to demonstrate accountability. Research (Mawby, 2010b) also tells us that, to service their needs, crime reporters require: $(A)$ accurate and timely information; (B) trust and honesty from police contacts; (C) access to police personnel; and (D) better understanding by the police of the nonmonolithic media. Any move towards greater regulation brings police objectives (1) and (5) above into play with the reporters' requirements $(A)$ and $(C)$.

History and research also tell us that if a more formal system is implemented, then methods of circumventing the system will emerge. Successive police attempts to professionalise their formal communication channels do not meet the complete needs of specialist crime reporters, who need something extra to the general information released to all media outlets. This trend can be traced back to each incremental stage in the development of police non-operational communications, e.g., 
establishing the first press office in 1919 to create a formal channel of communication did not close down the informal channels that had developed (Mawby, 2002).

Irrespective of whether the recording of all police-media contacts would resolve some of the perceived communication issues, it is not necessarily an appropriate or practical measure. In respect of appropriateness, it could be argued that a national solution is being imposed to resolve a Metropolitan Police problem. In terms of practicality, given the development of the workforce modernisation programme and the pluralisation of policing to include PCSOs, other designated officers and third party contractors, any new system would need to include not only police officers, but also these members of the extended police family. Arguably what is required is not more regulation, but more useful guidance that will encourage national consistency of good practices.

\section{New issues or revisited themes?}

During the recent reviews of police-media relations, a number of issues have been debated as though they were new and unexpected, however, several important threads can be traced to established themes in existing research into police-media relations. These include: the appropriateness of 'off-therecord' briefings; the practice of police forces employing former employees of media organisations; the arguments for and against deploying police officers as press officers and Heads of Corporate Communications; and differences in police national and local media relationships.

The ongoing examination of police-media contacts has suggested a state of unease around 'off-therecord' briefings and the closeness of some senior officers and press representatives. The very definition of 'off-the-record' has become a point of discussion and some clarification of this term, to be included in future ACPO guidance, would be a welcome outcome. However, it is important to note that background briefings and ongoing relations between senior officers and newspaper editors have been a constant feature of the development of police-media relations. This is neither novel, nor surprising. 
The benefits of developing relations and providing background briefings were identified in the 1930s when Lord Trenchard (Met Commissioner from 1931 to 1935) took to explaining to Fleet Street editors the reasons for his reforms before making them public, 'the mere fact of the Commissioner of Police taking editors into his confidence is calculated in itself to create a sympathetic attitude' (HowgraveGraham, 1947: 181). The practice of cultivating relations with newspaper editors has been maintained by Commissioners since Trenchard, from Sir Harold Scott in the 1940/50s to Sir Robert Mark in the 1970s to Sir John Stevens in the $21^{\text {st }}$ century (Stevens, 2006: 295) Hugh Orde in the present day. Chief

officers' memoirs have consistently remarked on the need for maintaining good relations with their equivalent heads of organisations in the media industry while at the same time expressing surprise that these relations were not more common (Scott, 1954; Sillitoe, 1955; Mark, 1977, 1978). Subsequently, off-the-record conversations and briefings have become part of the currency of police-media relations and are not restricted to chief officer level. Crime reporters value such communications which enable them to keep up-to-date, as well as forming part of their ongoing relationships with key sources. For example, a crime reporter with 40 years experience summed up the benefits thus, 'I like to deal with detectives. Most of the information is off-record and if I used it, that would be it - finished' (Mawby, 2010a).

\section{Resourcing and managing the press office}

HMIC's Without Fear or Favour report, published in December 2011, commented that it would be beneficial to explore the principle of service-wide standards for 'cooling off' periods for senior officers leaving the police service before accepting paid positions with media organisations. While it is understandable that criticisms have been made of senior officers who have left the service and shortly afterwards taken up paid work for national media organisations, there should be less surprise expressed at the practice of professional communicators leaving media organisations to join police forces. This 
practice is long-standing and was introduced by Sir Harold Scott, Met Commissioner from June 1945 to 1953. Scott increased the functions of the Press Bureau and appointed a 'Public Information Officer'. He was critical of the fact that the existing members of the Press Bureau were not experienced journalists and he appointed an experienced press officer and former employee of the BBC.

The recruitment of communications professionals was given impetus by the managerialist policies introduced in the 1980s which promoted effectiveness, efficiency and economy in the organisation of police work. Part of this included the movement of police officers out of the press office, encouraged by Home Office circulars $114 / 83$ and $105 / 88$ that promoted the civilianisation of posts on grounds of economy and specialist skills.

These push and pull influences have led to a transformation in the way that press offices have been resourced and managed in the last 20 years (cf. Schlesinger and Tumber, 1994:130-5). Three surveys conducted since 1996 illustrate the trend of departmental management moving into the domain of communications professionals and away from generalist police officer managers (Mawby, 2007a). Although West Midlands Chief Constable Chris Sims supported the model of having a chief inspector in charge of corporate communications in his evidence to the Leveson Inquiry, this is a minority view; this model is used in only a small number of forces (four in 2006-7 (Mawby, 2007a). The head of the communications department was a member of police staff in 38 forces $(90 \%)$ and only $2 \%$ of headquarters communications staff were police officers). The recruitment by police forces of trained and experienced media personnel is a feature of the professionalisation of police corporate communications and is a logical practice which it seems unreasonable to limit.

\section{The national and local media}

In the same way that the handling of the Stephen Lawrence case by the Met had profound implications for police forces throughout England and Wales, the focus on police-media relations has been instigated 
due to issues identified within the Met, but it has not always been acknowledged that police-media relations do not follow the formula of 'one case equals all cases'. The Met's media relations are more complex than other forces for a number of reasons, including: the Met's operational territory is the capital city, a 'goldfish bowl' for media attention; the Met's population includes a high proportion of newsworthy residents; the Met is by far the largest force in England and Wales, it has national policing responsibilities, e.g., for counter-terrorism, which attract media attention; and, for the Met, their local media are the national media. For these reasons, the Met has different media needs to other forces and it should not be assumed that the issues identified within the Met exist in other forces or that solutions devised for these issues will be appropriate across all forces.

Similarly it is problematic to assume that there is a settled one-dimensional police-media relationship that exists across the forces outside London. Academic studies of the police-media relationship have tended to argue that the relationship is either 'hegemonic' or 'subversive' (Reiner, 2007). Proponents of the former perspective point to the police as being in a position to provide access to information, to select and filter information, this placing them in a position of dominance in relation to media agencies, which become 'propagators of a dominant ideology'. In contrast, proponents of the latter perspective perceive the media as a threat to morality and authority, and fear that media representations undermine respect for the police service. However, as Reiner points out such crude oppositional analyses are simplistic and understate the complexity of the dynamics of the police-media relationship. These dynamics differ at local and national levels, across police forces and media formats; they differ across time and within the circumstances of individual newsworthy events (Mawby, 2002). Consequently police-media relations are constantly in tension and subject to negotiation.

Nevertheless, research suggests clear differences in police forces' relations with the national and local media. The local media seek to build long-term relationships with local officers, police stations and press 
offices that will provide a consistent supply of information to fill space in newspapers, radio and television programmes. In contrast, relations between the national media and local police forces tend to be more ephemeral. The national media are less interested in nurturing relationships as they are usually focusing on one story before leaving the area. On occasions they are seen as more aggressive and less trustworthy than the local media by local forces. This view is shared by local crime reporters who are wary of the national media descending on their area for particular stories and upsetting the normal pattern of relations, leaving the local media to repair and rebuild their relationships with the police. As one reporter commented, 'To them I become equal scum to The Star, The Sun, The News of the World' (Mawby, 2010a).

\section{Conclusion: Towards a workable police-media framework?}

Taking into account the Leveson Inquiry and the other (above-mentioned) reviews of police-media relations, it is clear that change is afoot. At the very least there is a need to address the lack of guidance around maintaining the integrity of relationships between police and media personnel. Nevertheless, the foregoing examination of the history of police-media relations, coupled with consideration of some of the themes established through research studies, suggests that things will not necessarily be improved by over-regulating contacts between police officers and the media, by imposing a 'one-size fits all' model of communications across all forces, or by returning uniformed officers to resource and manage force corporate communications departments. Nevertheless, police-media relations could be improved through the encouragement of greater consistency in police leadership and the provision of more comprehensive, structured guidance for all force personnel, and its dissemination including through training. 
Changes could be made at national, regional and force levels. At national level, the importance of police-media relations and communication in general as a core component of police legitimacy could be signalled by creating a new ACPO Business Area of 'communications', thus elevating the current 'portfolio' status of the ACPO Communications Advisory Group. The ACPO lead would then be responsible for overseeing the ongoing work of ACPO CAG to develop more comprehensive guidance on matters of appropriate contact, integrity and acceptable hospitality, together with clarification of terminology (including 'off-the-record') and the development of protocols of mutual expectations for police and media personnel. In addition, the establishment of national standards for police-media relations should be looked into, as long as these are not interpreted as minimum service standards that reduce current quality levels or alternatively as pointless performance indicators that do not reflect practice on the ground.

At the regional level, there is scope for the further development of collaborative training across forces to spread best practice and to learn from signal cases such as the Milly Dowler and Joanna Yeates investigations and their respective media experiences. Protocols for mutual aid arrangements during exceptional investigations and emergency situations, and arrangements for media trouble-shooters to move between forces as situations develop, as under development currently by ACPO CAG, are also entirely sensible.

At the level of individual forces, the key improvement would be for each force to have a communications champion at ACPO level and for the corporate communications department to have a direct line of communication to the designated ACPO officer. A clear organisational reporting and accountability structure modelled on a national standard should head-off the comment that corporate communications needs a uniformed manager to establish its in-force organisational credibility and status. Each force should have a consistent policy (and standards and rules) that apply to all staff for 
media contacts. In principle all police personnel should be authorised to liaise with the media, subject to taking advice from the communications department, complying with legal and policy requirements, seeking clearance from a manager and speaking only about subjects within their responsibility and knowledge. To support this at force level there is a clear need to increase the level of training and guidance on media relations, and communications more generally, at key career stages, e.g., at probationer, promotion and specialisation career points. HMIC would have a role to play in encouraging and reporting on compliance.

To develop a layered package of improvements along these lines would be research-informed and cognisant of the historical development of media relations. It would also reinforce that communication is central to modern policing. As HMIC (2011: 4) has recognised the police service must be 'absolutely transparent' to maintain public confidence by not only being fair, but also in being seen to be fair. One route to this is for forces to recognise the role that corporate communications departments have to play and to draw on them to build-in, rather than bolt-on, communications as a key component of legitimate policing.

\section{References}

Cartmell, M. and Green, N. (2011). 'Under arrest: police budgets.' PRWeek 17 November 2011.

Chibnall, S. (1977). Law-and-Order News: An analysis of crime reporting in the British Press. London: Tavistock Publications.

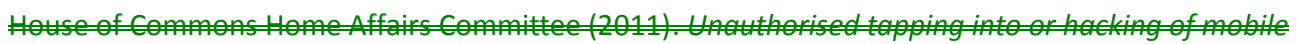

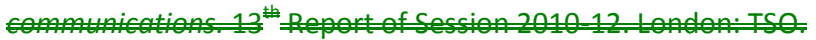

Feist, A. (1999). The Effective Use of the Media in Serious Crime Investigations. Policing and Reducing Crime Unit paper 120. London: Home Office. 
Filkin, E. (2011). The Ethical Issues arising from the Relationship between Police and Media. Advice to the Commissioner of Police of the Metropolis and his Management Board. London: MPS.

HMIC (2011). Without fear or favour: A review of police relationships. London: HMIC.

House of Commons Home Affairs Committee (2011). Unauthorised tapping into or hacking of mobile

communications. $13^{\text {th }}$ Report of Session 2010-12. London: TSO.

Howgrave-Graham, H.M. (1947). Light and Shade at Scotland Yard. London: John Murray.

Innes, M. (1999). 'The media as an investigative resource in murder enquiries.' British Journal of Criminology 39 (2): 269-86.

Leishman, F. and Mason, P. (2003). Policing and the Media: Facts Fictions and Factions. Cullompton: Willan Publishing.

Macready, Sir N. (1924). Annals of an active life, volume 2. London: Hutchinson.

Mark, R. (1977). Policing a Perplexed Society. London: George Allen \& Unwin Ltd.

Mark, R. (1978). In the office of Constable. London: Collins and Son.

Mawby, R.C. (2002). Policing Images: policing, communication and legitimacy. Cullompton: Willan.

Mawby, R.C. (2007a). Police Service Corporate Communications: A Survey of forces in England, Wales and Scotland. Birmingham: University of Central England.

Mawby, R.C. (2007b). 'Criminal Investigation and the Media' in Newburn, T., Williamson, T. and Wright, A. (eds), The Handbook of Criminal Investigation. Cullompton: Willan Publishing, 146-69.

Mawby, R.C. (2010a). 'Chibnall Revisited: Crime reporters, the police and "law-and-order news".' British Journal of Criminology 50 (6): 1060-1076. 
Mawby, R.C. (2010b). 'Police corporate communications, crime reporting, and the shaping of policing news.' Policing and Society 20 (1): 124-139.

Reiner, R. (2007). 'Media made criminality: the representation of crime in the mass media' in Maguire, M., Morgan, R. and Reiner, R. (eds), The Oxford Handbook of Criminology, $4^{\text {th }}$ edn. Oxford: Oxford University Press, 302-337.

Schlesinger, P. and Tumber, H. (1994). Reporting Crime: The Media Politics of Criminal Justice. Oxford: Oxford University Press.

Scott, Sir H. (1954). Scotland Yard. Harmondsworth: Penguin.

Sillitoe, P. (1955). Cloak without dagger. London: Pan Books Ltd.

Stevens, J. (2006). Not for the faint-hearted, revised edition. London: Phoenix.

Wilson, D., Howe, N., Kemp, D. and Tolputt, H. (2011). 'Servicing the media's needs at arm's length: Police-media relations during high-profile murder investigations.' Policing: A Journal of Policy and Practice 5(4):343-355.

\footnotetext{
${ }^{1}$ The police, the media and their audiences (Grant reference RES-000-22-1921). See http://www.esrc.ac.uk/myesrc/grants/RES-000-22-1921/read
} 